\title{
Reducing bumblefoot lesions in a group of captive Magellanic penguins (Spheniscus magellanicus) with the use of environmental enrichment ${ }^{1}$
}

\author{
Laura Reisfeld ${ }^{2 *}$, Mayla Barbirato², Laura Ippolito², Ricardo Cesar Cardoso², \\ Marcílio Nichi ${ }^{3}$, Manuela G.F.G. Sgai ${ }^{3}$ and Cristiane S. Pizzutto ${ }^{3}$
}

\begin{abstract}
Reisfeld L., Barbirato M., Ippolito L., Cardoso R.C., Nichi M., Sgai M.G.F.G. \& Pizzutto C.S. 2013. Reducing bumblefoot lesions in a group of captive Magellanic penguins (Spheniscus magellanicus) with the use of environmental enrichment. Pesquisa Veterinária Brasileira 33(6):791-795. Departamento de Reprodução Animal, Faculdade de Medicina Veterinária e Zootecnia, Universidade de São Paulo, Avenida Prof. Dr. Orlando Marques de Paiva 87, Cidade Universitária, São Paulo, SP 05508-270, Brazil. E-mail: lauravet@aquariodeaopaulo.com.br

Captive penguins are prone to pododermatitis (bumblefoot) lesions due to sedentary habits, changes in normal activity patterns, prolonged time on hard and abrasive surfaces, and less time swimming in the water. Environmental enrichment allows the use of creative and ingenious techniques that aim to keep the captive animals occupied by increasing the range and the diversity of behavioral opportunities always respecting the ethological needs of the species. The main goal of this work was to use environmental enrichment techniques to reduce pododermatitis in a group of captive penguins. Five captive Magellanic penguins (Spheniscus magellanicus) that were showing bumblefoot lesions were followed during this project. To monitor the lesions, all animals were physically restraint 3 times a week over a period of 12 weeks. Environmental enrichment was introduced daily in the water with the goal of enhancing their time in the water for one extra hour daily. The results demonstrate that in a twelve weeks period, four animals showed significant reduction of the lesions in both feet and in two animals the lesions were completely healed. With these results we can conclude that aquatic environmental enrichment allowed this group of penguins to spend more time in the water, favoring the reduction of the bumblefoot lesions.
\end{abstract}

INDEX TERMS: Birds, pododermatitis, bumblefoot, captive, environmental enrichment, penguins, Spheniscus magellanicus.

RESUMO.- [A redução do bumblefoot com a utilização de enriquecimento ambiental para um grupo de pinguim-de-Magalhães (Spheniscus magellanicus) mantido em cativeiro.] Os pinguins cativos estão predispostos a pododermatite (bumblefoot) devido ao sedentarismo, mudanças dos padrões normais de atividade, tempo prolongado de permanência em pisos duros e abrasivos, diminuição da natação e tempo na água. 0 enriquecimento ambiental permite a utilização de técnicas imaginativas e engenhosas

\footnotetext{
${ }^{1}$ Received on January 10, 2013.

Accepted for publication on April 19, 2013.

${ }^{2}$ Aquário de São Paulo, Rua Huet Bacelar 407, Ipiranga, São Paulo, SP 04275000, Brazil. *Corresponding author: lauravet@aquariodeaopaulo.com.br

${ }^{3}$ Departamento de Reprodução Animal, Faculdade de Medicina Veterinária e Zootecnia (FMVZ), Universidade de São Paulo (USP), Av. Prof. Dr. Orlando Marques de Paiva 87, Cidade Universitária, São Paulo, SP 05508270. E-mail: cspizzutto@yahoo.com.br
}

que visam manter os animais cativos ocupados e com uma maior diversidade de oportunidades comportamentais, sempre respeitando as necessidades etológicas da espécie. 0 objetivo deste trabalho foi utilizar técnicas de enriquecimento ambiental para reduzir as lesões de pododermatite em um grupo de pingüins. Cinco indivíduos da espécie Pinguim-de-Magalhães (Spheniscus magellanicus) foram monitorados durante este projeto. Todos os animais foram contidos fisicamente 3 vezes por semana para a realização do acompanhamento do tamanho das lesões, durante 12 semanas. Enriquecimento ambiental foi introduzido diariamente na água, objetivando aumentar em uma hora o tempo em que os animais passavam na água. Os resultados mostraram que, ao longo das 12 semanas, 4 animais apresentaram redução significativa das lesões em ambas as patas, sendo que em dois animais as lesões desapareceram. Com isto, podemos concluir que o enriquecimento 
ambiental aquático para este grupo de pingüins permitiu um maior tempo de permanência dos animais na água favorecendo a redução das lesões de bumblefoot.

TERMOS DE INDEXAÇÃO: Pinguim-de-Magalhães, Spheniscus magellanicus. cativeiro, pododermatite, bumblefoot, enriquecimento ambiental.

\section{INTRODUCTION}

The most common penguin species found on the coast of Brazil is the Magellanic penguin (Spheniscus magellanicus). This species is distributed along the Argentinean Coast, the Chilean Coast and the Falkland Islands. The migration process starts by the end of February, when penguins head towards the Brazilian Coast searching for increased offer of food. Debilitated animals are rescued at the beaches and taken to the rehabilitation centers, and later on in some cases, they are sent to zoos and aquariums (Ruopollo et al 2004).

Almost all species of penguins spend most of their time foraging for food in the ocean and the rest of their time is spent on land, where they reproduce and molt (Stoskopf \& Stoskopf 1986, Williams 1995).

Captive penguins are prone to pododermatitis lesions due to sedentary habits, changes in normal activity patterns, prolonged time in hard and abrasive surfaces, and less time swimming in the water (Wallace \& Walsh 2005). Bumblefoot is the common name of pododermatitis in birds. It is characterized by excoriations, ulcerations and plantar epithelium abscesses. If not treated, these lesions can evolve from excoriations to osteomyelitis (Oaks 1993, Redig 1993).

According to Cooper (1978), the lesions can be classified in 3 different grades according to its gravity, involved area and prognosis. In grade 1, injury is mild and localized; the epithelium is thinner and proliferative, may or may not increase in temperature and volume. In grade 2 , injury is more extensive and bacterial infections are usually present, causing increased temperature and volume on the site. In grade 3 , an extension of the lesion and presence of an infectious and degenerative process is observed and may involve other structures. In this case the foot becomes intermittently hot and painful (Redig 1993, Harcourt 2000).

Treatment can be performed with topical or systemic antibiotics. Debridement of lesions might be necessary depending on the case. The use of bandages is recommended to reduce the impact and pressure on the lesion (Degernes 1994).

It is recommended to encourage the animals to spend more time with different activities in the water. This can be accomplished through environmental enrichment, including the use of different forms of feeding (Wallace \& Walsh 2005).

Environmental enrichment allows the use of creative and ingenious techniques that aim to keep the captive animals occupied by increasing the range and the diversity of behavioral opportunities, always respecting the ethological needs of the species (Shepherdson 1998).

Offering different surfaces, objects and toys can provide different stimuli, novelty and complexity to the animals (Maple \& Perkins 1996). Simple structural modifications, changes in daily routine and their own socialization are sufficient measures to stimulate and improve the status and psychological well being of a group of animals (Boere 2001).
The goals are usually achieved when the typical behavior of the studied species is enhanced and reduction in abnormal behavior is observed (Bloomsmith et al. 1991). The main goal of this work was to use environmental enrichment techniques to reduce bumblefoot lesions in a group of captive penguins.

\section{MATERIALS AND METHODS}

Five Magellanic penguins (Spheniscus magellanicus) at exhibition at the Aquário de São Paulo were followed throughout this project. The animals arrived at the institution in July 2008. They were all juveniles that came from rehabilitation centers distributed along the coast of Brazil. At the period of this study the penguin exhibit had an 18.0001 salt water pool and a dry area, which presents $50 \%$ of synthetic grass and $50 \%$ of pebbles of different sizes. The water and air temperature was maintained at $23-24^{\circ} \mathrm{C}$ and $21-22^{\circ} \mathrm{C}$ respectively. The air humidity was kept between $70-80 \%$. The animals were hand fed 3 times a day. Each animal consumes 300-400g fish/day. One hour before the first feeding, vitamin supplementation is provided once daily.

After 6 months in captivity they started showing bumblefoot lesions on both feet. During physical restraint, the lesions were cleaned with a $2 \%$ chlorexidine solution. Followed by this procedure, the animals were placed in foot bath with Chamomile tea. After 15 minutes, the animals were restrained and a gel (DM-GEL ${ }^{\circledR}$, Vetnil ${ }^{\circledR}$, Louveira, SP) was massaged in their feet. Once that procedure was done, a Banana Skin Tanine Gel (Compounding pharmacy) with bacterial and healing properties was applied directly on the ulcers. After that, to lessen the pressure on the feet, gauze and elastic bandage was applied Vetrap ${ }^{\circledR}, 3 \mathrm{M}^{\circledR}$, EUA.

This treatment was performed during 1 year, before introducing environmental enrichment and, the size of the lesions remained unchanged throughout this period. The treatment was maintained while environmental enrichment techniques were applied to the animals.

To follow the healing progress of lesions, the animals were physically restrained three times a week, for twelve weeks. For each foot (left and right) three measures were established: Vertical border to border, horizontal border to border and foot size (foot circumference) (Fig.1). Measures were obtained with a pachymeter and lesions were photographed every time. All the measurements were always performed by the same person to avoid errors and differences in the measurements.

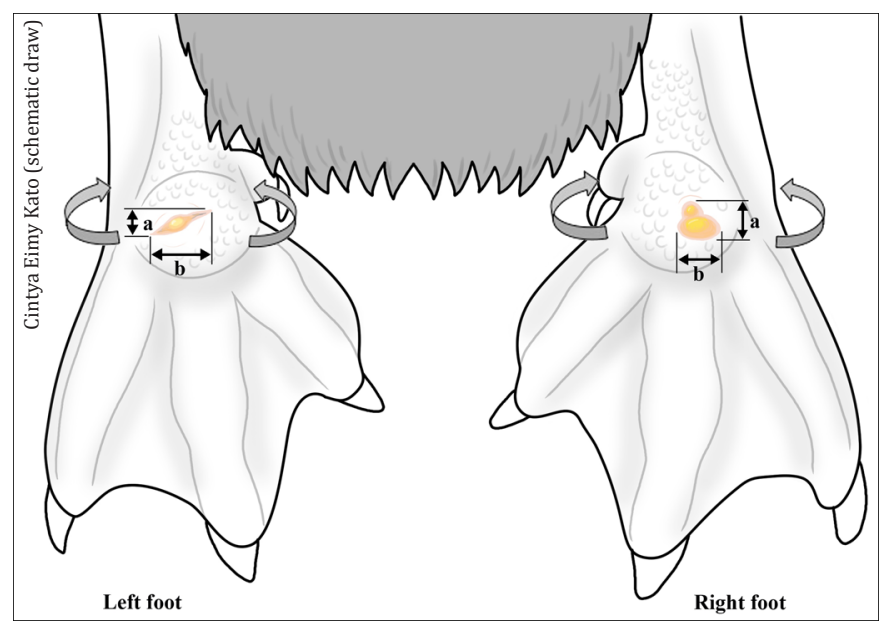

Fig.1. Schematic drawing showing measurements of bumblefoot lesion of right and left feet of a Magellanic penguin (Spheniscus magellanicus): (a) Vertical border-to-border; (b) Horizontal border-to-border; foot circumference (circular arrows). 


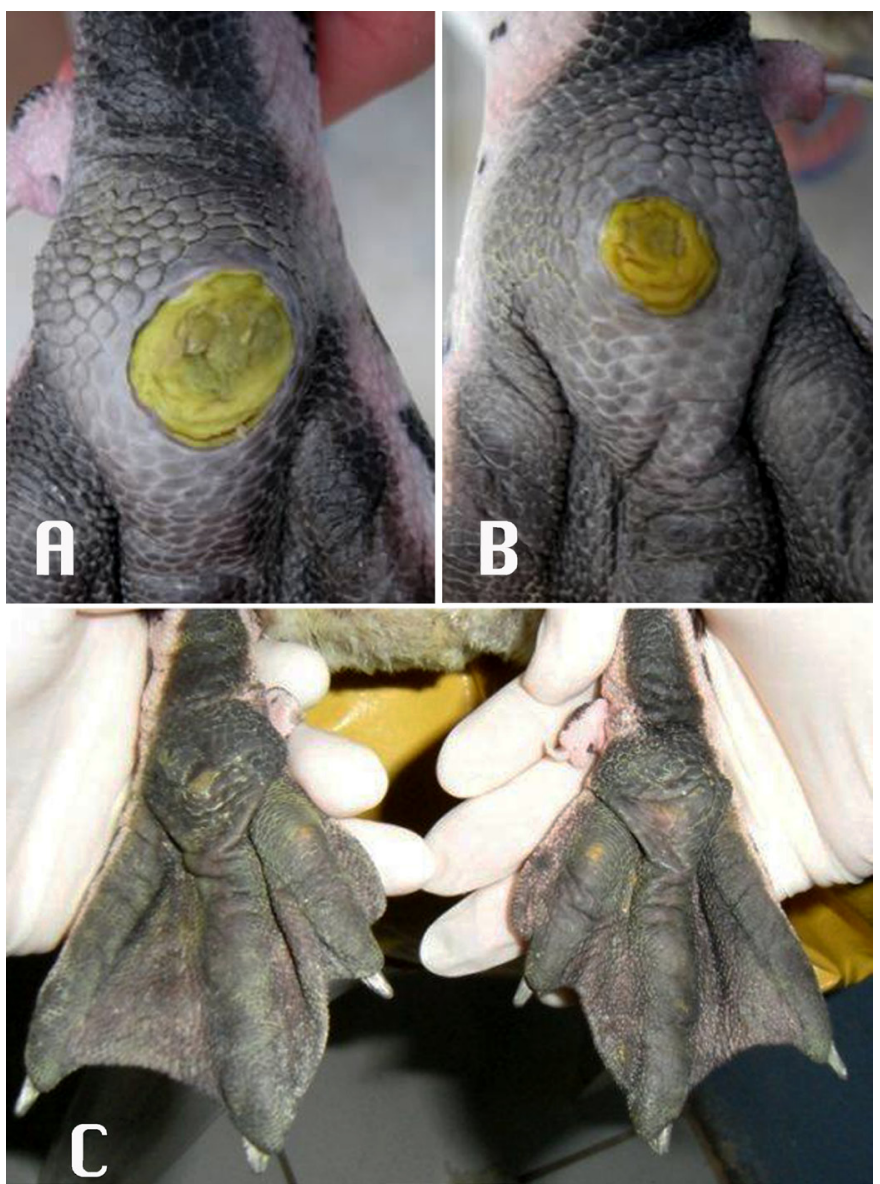

Fig.2. Evolution of bumblefoot lesions on a Magellanic penguin (Spheniscus magellanicus): (A) advanced stage lesion, (B) on healing process, (C) healed lesion.

Table 1. Penguin 1: Mean and standard deviation (SD) of weekly measurements of bumblefoot lesion size and foot circumference of captive Magellanic penguin (Spheniscus magellanicus), subjected to environmental enrichment for 12 weeks, Aquário de São Paulo, 2011

\begin{tabular}{|c|c|c|c|c|c|c|}
\hline \multirow[t]{3}{*}{ Week } & \multicolumn{4}{|c|}{ Lesion $(\mathrm{cm}) \pm \mathrm{SD}$} & \multicolumn{2}{|c|}{ Foot $(\mathrm{cm}) \pm S D$} \\
\hline & \multicolumn{2}{|c|}{ Left } & \multicolumn{2}{|c|}{ Right } & \multirow[t]{2}{*}{ Left } & \multirow[t]{2}{*}{ Right } \\
\hline & Vertical & Horizontal & Vertical & Horizontal & & \\
\hline 1 & $1,3 \pm 0,57$ & $5 \pm 0$ & $3,6 \pm 1,15$ & $2 \pm 1,70$ & $8,5 \pm 0$ & $8,9 \pm 0,40$ \\
\hline 2 & $1,5 \pm 1,00$ & $4,6 \pm 0,58$ & $3,3 \pm 1,53$ & $2 \pm 0,90$ & $7,9 \pm 0,40$ & $8,2 \pm 0,36$ \\
\hline 3 & $2 \pm 0$ & $5,3 \pm 0,58$ & $5 \pm 0$ & $1,8 \pm 0,30$ & $8,2 \pm 0,30$ & $8,2 \pm 0,32$ \\
\hline 4 & $1,6 \pm 0,57$ & $4,3 \pm 0,29$ & $3,8 \pm 0,76$ & $2,1 \pm 0,30$ & $8,1 \pm 0,10$ & $8 \pm 0,20$ \\
\hline 5 & $2,1 \pm 0,57$ & $3 \pm 0$ & $3,3 \pm 0,58$ & $2,3 \pm 0,60$ & $7,9 \pm 0,20$ & $8 \pm 0,17$ \\
\hline 6 & $0,5 \pm 0,86$ & $1 \pm 1,73$ & $1,3 \pm 2,31$ & 1 & $7,8 \pm 0,10$ & $7,8 \pm 0,25$ \\
\hline 7 & 0 & 0 & 0 & 0 & $7,4 \pm 0,10$ & $7,4 \pm 0,05$ \\
\hline 8 & 0 & 0 & 0 & 0 & $7,4 \pm 0$ & $7,4 \pm 0$ \\
\hline 9 & 0 & 0 & 0 & 0 & $7,4 \pm 0,10$ & $7,5 \pm 0,17$ \\
\hline 10 & 0 & 0 & 0 & 0 & $7,4 \pm 0,10$ & $7,4 \pm 0,10$ \\
\hline 11 & 0 & 0 & 0 & 0 & $7,5 \pm 0$ & $7,4 \pm 0,10$ \\
\hline 12 & 0 & 0 & 0 & 0 & $7,6 \pm 0,2$ & $7,4 \pm 0,11$ \\
\hline
\end{tabular}

Along with the treatment described above the animals were stimulated to stay one more hour daily in the water with the use of aquatic environmental enrichment. The items used for enrichment were: plastic colored balls and rings, bubbles, hula hoop rings, ice blocks with fish and live fish, natural shells. Only two items were introduced daily.

Weekly means values were used. Results were reported as untransformed means +/- S.E.M.
Table 2. Penguin 2: Mean and standard deviation (SD) of weekly measurements of bumblefoot lesion size and foot circumference of captive Magellanic penguin (Spheniscus magellanicus), subjected to environmental enrichment for 12 weeks, Aquário de São Paulo, 2011

\begin{tabular}{|c|c|c|c|c|c|c|}
\hline \multirow[t]{3}{*}{ Week } & \multicolumn{4}{|c|}{ Lesion $(\mathrm{cm}) \pm S D$} & \multicolumn{2}{|c|}{ Foot $(\mathrm{cm}) \pm \mathrm{DP}$} \\
\hline & \multicolumn{2}{|c|}{ Left } & \multicolumn{2}{|c|}{ Right } & \multirow[t]{2}{*}{ Left } & \multirow[t]{2}{*}{ Right } \\
\hline & Vertical & Horizontal & Vertical & Horizontal & & \\
\hline 1 & $5 \pm 0,57$ & 5 & $7,3 \pm 0,29$ & 6.5 & $9,3 \pm$ & $8,3 \pm 0,28$ \\
\hline 2 & 7 , & $9,5 \pm$ & $11,3 \pm$ & & & \\
\hline 3 & 7, & $8,8 \pm$ & 11,6 & & & 8,1 \\
\hline 4 & 7,5 & $8,1 \pm$ & 10,6 & $6 \pm$ & 9,3 & 8,5 \\
\hline 5 & $6,3=$ & $7,2 \pm$ & $9,6 \pm$ & $6 \pm$ & 9,4 & 8,4 \\
\hline 6 & $7,3 \pm$ & $7,8 \pm$ & 10,3 & $8,5 \pm$ & 8,9 & 9,5 \\
\hline 7 & 6. & $7=$ & $9,8 \pm$ & $8,3 \pm$ & $8,2 \pm$ & $8,9 \pm$ \\
\hline 8 & $, 3 \pm 0,43$ & $5,9 \pm$ & $7,8 \pm$ & 8,1 & $8 \pm 0$ & $8,7 \pm 0,20$ \\
\hline 9 & $2,7 \pm 0,51$ & $3,8 \pm 1,76$ & $6,2 \pm$ & $5,3 \pm$ & 7,9 & $8,5 \pm 0,17$ \\
\hline 10 & 0 & 0 & $4,8 \pm$ & $3,1 \pm$ & $7,8 \pm 0,20$ & $8,3 \pm 0,10$ \\
\hline 11 & 0 & 0 & $3,5 \pm 0,10$ & $2,9 \pm 0,10$ & $7,8 \pm 0,10$ & $8,3 \pm 0,26$ \\
\hline 12 & 0 & 0 & & 0 & $\pm 0,30$ & $8,3 \pm 0,43$ \\
\hline
\end{tabular}

Table 3. Penguin 3: Mean and standard deviation (SD) of weekly measurements of bumblefoot lesion size and foot circumference of captive Magellanic penguin (Spheniscus magellanicus), subjected to environmental enrichment for 12 weeks, Aquário de São Paulo, 2011

\begin{tabular}{|c|c|c|c|c|c|c|}
\hline \multirow{3}{*}{ Week } & \multicolumn{4}{|c|}{ Lesion $(\mathrm{cm}) \pm \mathrm{SD}$} & \multicolumn{2}{|c|}{ Foot $(\mathrm{cm}) \pm \mathrm{DP}$} \\
\hline & \multicolumn{2}{|c|}{ Left } & \multicolumn{2}{|c|}{ Right } & \multirow[t]{2}{*}{ Left } & \multirow[t]{2}{*}{ Right } \\
\hline & Vertical & Horizontal & Vertical & Horizontal & & \\
\hline 1 & $6 \pm 0$ & $5,3 \pm 0,58$ & $2,3 \pm 0,58$ & $1,3 \pm 0,60$ & $7,3 \pm 0,60$ & $7,8 \pm 0,50$ \\
\hline 2 & $1 \pm 0,50$ & $3,6 \pm 0,58$ & $1 \pm 0$ & $1,6 \pm 0,30$ & $7,4 \pm 0,40$ & $7,8 \pm 0,61$ \\
\hline 3 & $5,3 \pm 0,28$ & $4,3 \pm 0,29$ & $1,6 \pm 0,58$ & $1,5 \pm 0$ & $7,7 \pm 0,10$ & $8 \pm 0,11$ \\
\hline 4 & $5,1 \pm 0,28$ & $4 \pm 0,50$ & $1,5 \pm 0$ & $1,6 \pm 0,30$ & $7,8 \pm 0,40$ & $8 \pm 0$ \\
\hline 5 & $3,5 \pm 2,50$ & $2 \pm 1,73$ & $2 \pm 0$ & $1,8 \pm 0,60$ & $7,4 \pm 0,20$ & $7,7 \pm 0,20$ \\
\hline 6 & 0 & 0 & $2,3 \pm 0,29$ & $3,5 \pm 1,70$ & $7,5 \pm 0,50$ & $7,6 \pm 0,40$ \\
\hline 7 & 0 & 0 & $2 \pm 0$ & $3 \pm 0$ & $7,2 \pm 0,20$ & $8,1 \pm 0,49$ \\
\hline 8 & 0 & 0 & $2 \pm 0$ & $2,8 \pm 0,10$ & $7,2 \pm 0$ & $8 \pm 0,10$ \\
\hline 9 & 0 & 0 & $1,6 \pm 0,36$ & $2,3 \pm 0,20$ & $7,5 \pm 0,10$ & $7,9 \pm 0,10$ \\
\hline 10 & 0 & 0 & $0,8 \pm 0,61$ & $1,7 \pm 0,60$ & $7,2 \pm 0$ & $7,9 \pm 0,10$ \\
\hline 11 & 0 & 0 & 0 & 0 & $7,3 \pm 0,10$ & $7,8 \pm 0$ \\
\hline 12 & 0 & 0 & 0 & 0 & $7,3 \pm 0,10$ & $7,8 \pm 0,15$ \\
\hline
\end{tabular}

\section{RESULTS}

In two animals, the lesions found on both feet completely disappeared after some weeks of enrichment (Fig.2, Table 1 to 5 ).

For Penguin 1, the lesions found on both feet disappeared after the $7^{\text {th }}$ week after the beginning of enrichment. A decrease in the size of the lesion was observed between the $5^{\text {th }}$ to $6^{\text {th }}$ week in both length and width when compared to the previous weeks. After the $7^{\text {th }}$ week, foot size remained stable (Fig.3a).

In Penguin 2, the lesions completely disappeared only in the left foot, which happened in the $10^{\text {th }}$ week of enrichment. In this case, an improvement was observed after 5 to 7 weeks of enrichment. In the right foot, lesions were still visible after the $12^{\text {th }}$ week. However, an improvement was observed in the $10^{\text {th }}$ week when compared to the first week of enrichment (length: $4.80 \pm 0.69$ vs. $7.33 \pm 0.17 \mathrm{~cm}$; width: $3.1 \pm 0.58$ vs. $6.5 \pm 0$ respectively, Fig. $3 \mathrm{~b}$ ).

In Penguin 3, the lesions in the left foot disappeared after the $6^{\text {th }}$ week of enrichment. However, in the right foot such improvement was only observed 10 to 11 weeks after the 
Table 4. Penguin 4: Mean and standard deviation (SD) of weekly measurements of bumblefoot lesion size and foot circumference of captive Magellanic penguin (Spheniscus magellanicus), subjected to environmental enrichment for 12 weeks, Aquário de São Paulo, 2011

\begin{tabular}{|c|c|c|c|c|c|c|}
\hline \multirow[t]{3}{*}{ Week } & \multicolumn{4}{|c|}{ Lesion $(\mathrm{cm}) \pm \mathrm{SD}$} & \multicolumn{2}{|c|}{ Foot $(\mathrm{cm}) \pm S D$} \\
\hline & \multicolumn{2}{|c|}{ Left } & \multicolumn{2}{|c|}{ Right } & \multirow[t]{2}{*}{ Left } & \multirow{2}{*}{ Right } \\
\hline & Vertical & Horizontal & Vertical & Horizontal & & \\
\hline 1 & $3,3 \pm 0,57$ & $2,6 \pm 0,58$ & 0 & 0 & $8,0 \pm 0$ & $8,3 \pm 0,57$ \\
\hline 2 & $4,1 \pm 0,28$ & $2,6 \pm 0,58$ & 0 & 0 & $8,1 \pm 0,30$ & $8,9 \pm 0,50$ \\
\hline 3 & $5,0 \pm 0$ & $3,6 \pm 0,53$ & 0 & 0 & $8,3 \pm 0,20$ & $9,0 \pm 0,10$ \\
\hline 4 & $4,0 \pm 0$ & $3,6 \pm 0,29$ & 0 & 0 & $8,6 \pm 0,50$ & $9,4 \pm 0,57$ \\
\hline 5 & $4,0 \pm 0$ & $2,8 \pm 0,29$ & 0 & 0 & $8,9 \pm 0,20$ & $9,1 \pm 0,15$ \\
\hline 6 & $3,6 \pm 1,52$ & $2,5 \pm 0,87$ & 0 & 0 & $8,2 \pm 0,10$ & $8,7 \pm 0,49$ \\
\hline 7 & $1,3 \pm 0,28$ & $1,5 \pm 0,50$ & 0 & 0 & $8,4 \pm 1,00$ & $8,2 \pm 0,25$ \\
\hline 8 & $1,8 \pm 0,10$ & $1,5 \pm 0,50$ & 0 & 0 & $8,5 \pm 0$ & $8,3 \pm 0$ \\
\hline 9 & $2,0 \pm 0,20$ & $2,5 \pm 0,10$ & 0 & 0 & $8,7 \pm 0,10$ & $8,1 \pm 0,17$ \\
\hline 10 & $1,6 \pm 0,20$ & $2,0 \pm 0,20$ & 0 & 0 & $8,5 \pm 0,10$ & $8,3 \pm 0,10$ \\
\hline 11 & $1,8 \pm 0,10$ & $1,9 \pm 0,10$ & 0 & 0 & $8,7 \pm 0,10$ & $8,3 \pm 0$ \\
\hline 12 & $2,3 \pm 0,57$ & $2,1 \pm 0,29$ & 0 & 0 & $8,9 \pm 0,20$ & $8,3 \pm 0,17$ \\
\hline
\end{tabular}
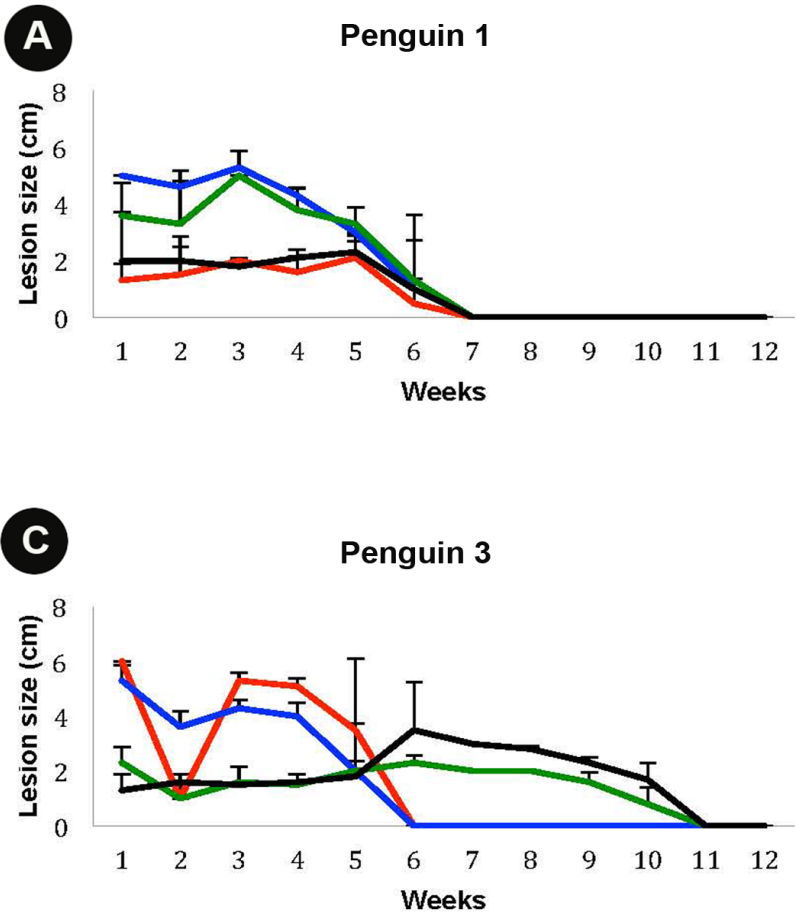

Table 5. Penguin 5: Mean and standard deviation (SD) of weekly measurements of bumblefoot lesion size and foot circumference of captive Magellanic penguin (Spheniscus magellanicus), subjected to environmental enrichment for 12 weeks, Aquário de São Paulo, 2011

\begin{tabular}{|c|c|c|c|c|c|c|}
\hline \multirow[t]{3}{*}{ Week } & \multicolumn{4}{|c|}{ Lesion $(\mathrm{cm}) \pm S D$} & \multicolumn{2}{|c|}{ Foot $(\mathrm{cm}) \pm \mathrm{DD}$} \\
\hline & \multicolumn{2}{|c|}{ Left } & \multicolumn{2}{|c|}{ Right } & \multirow[t]{2}{*}{ Left } & \multirow[t]{2}{*}{ Right } \\
\hline & Vertical & Horizontal & Vertical & Horizontal & & \\
\hline 1 & $5 \pm 0$ & $1,6 \pm 0,29$ & $3,0 \pm 0$ & $=0$ & $8 \pm 0,30$ & $10,0 \pm 0$ \\
\hline 2 & $2,8 \pm 0,28$ & $1,6 \pm 0,58$ & $2,5 \pm 0,50$ & $4,3 \pm 0,60$ & $9,2 \pm 0,40$ & $9,8 \pm 0,05$ \\
\hline 3 & $2,6 \pm 0,57$ & $2,1 \pm 1,15$ & $3,3 \pm 1,15$ & $4,0 \pm 0,90$ & $9,3 \pm 0,30$ & $10,3 \pm 0,15$ \\
\hline 4 & $2,0 \pm 0$ & $1,8 \pm 1,53$ & $3,1 \pm 1,53$ & $5,5 \pm 1,00$ & $9,3 \pm 0,20$ & $10,2 \pm 0,20$ \\
\hline 5 & $2,5 \pm 0$ & $1,8 \pm 0,29$ & $3,8 \pm 0,29$ & $5,1 \pm 0,30$ & $9,1 \pm 0,30$ & $10,2 \pm 0,55$ \\
\hline 6 & $2,6 \pm 1,15$ & $2,6 \pm 0,29$ & $6,0 \pm 2,29$ & $6,8 \pm 1,60$ & $9,1 \pm 0,30$ & $9,1 \pm 0,41$ \\
\hline 7 & $2,7 \pm 0,26$ & $1,8 \pm 0,29$ & $7,3 \pm 0,58$ & $7,3 \pm$ & $8,2 \pm 0,30$ & $9,0 \pm 0,26$ \\
\hline 8 & $2,5 \pm 0,10$ & $2,1 \pm 0,12$ & $6,8 \pm 0,2$ & $7,2 \pm$ & $8,2 \pm 0,10$ & $10,0 \pm 0,05$ \\
\hline 9 & $1,9 \pm 0,17$ & $1,7 \pm 0,10$ & $7,1 \pm 0,2$ & $7,3 \pm 0,20$ & $8,5 \pm 0$ & $10,2 \pm 0,10$ \\
\hline 10 & $1,7 \pm 0,36$ & $1,2 \pm 0,17$ & $8,4 \pm, 36$ & $7,9 \pm 0,10$ & $8,3 \pm 0,20$ & $10,3 \pm 0,10$ \\
\hline 11 & $1,6 \pm 0,10$ & $1,2 \pm 0$ & $8,0 \pm 0,10$ & $8,1 \pm 0,10$ & $8,4 \pm 0,10$ & $10,5 \pm 0$ \\
\hline 12 & $1,6 \pm 0,28$ & $1,1 \pm 0,29$ & $9,1 \pm 0,76$ & $8,3 \pm 0,90$ & $8,3 \pm 0,30$ & $10,5 \pm 0,05$ \\
\hline
\end{tabular}

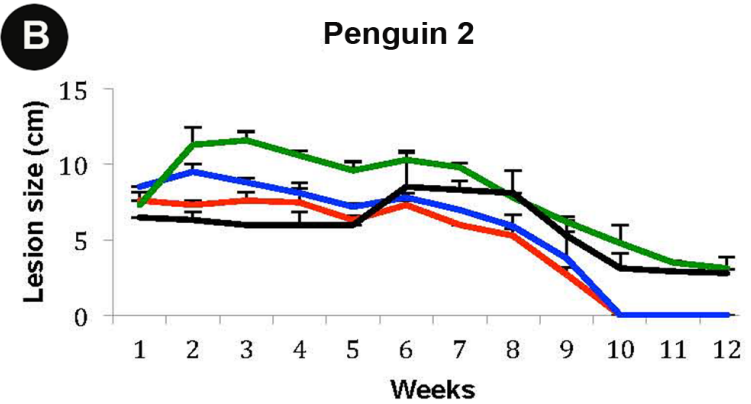

D

Penguin 4

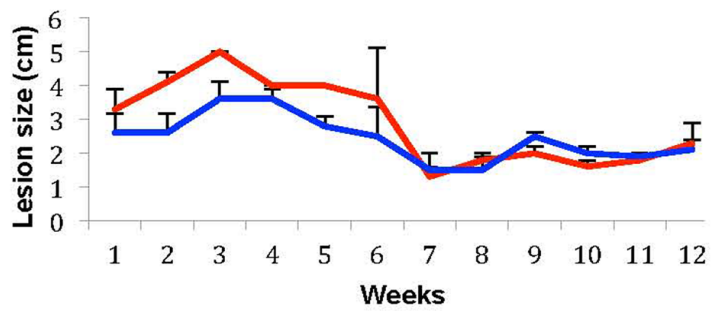

E

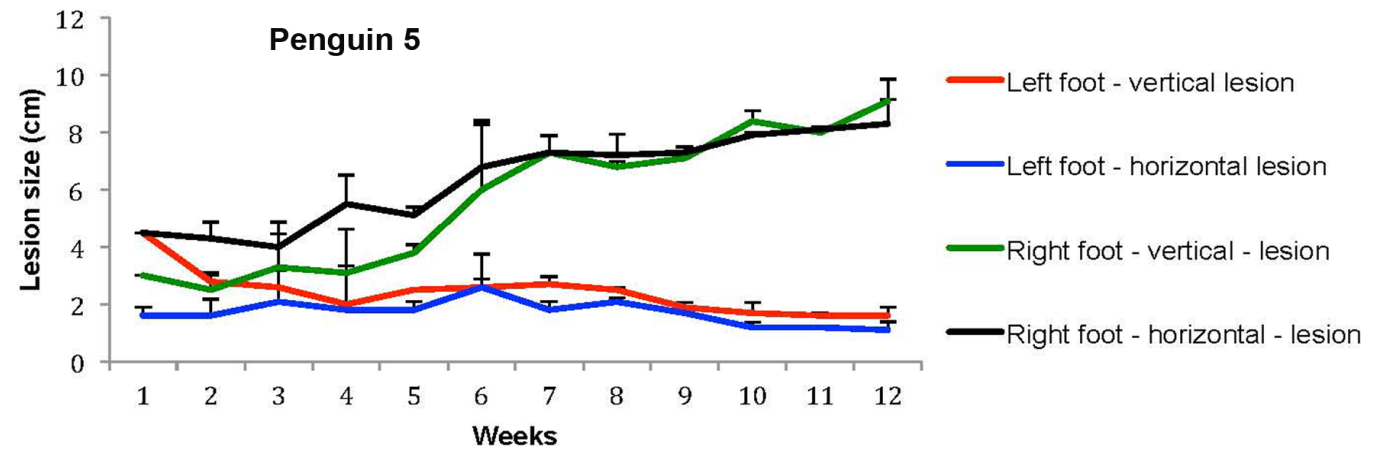

Fig.3. Bumblefoot lesions evolution (A, B, C, E) throughout the 12 weeks of treatment and aquatic environmental enrichment in a captive Magellanic penguin (Spheniscus magellanicus) at Aquário de São Paulo. 
beginning of enrichment (length: $6.0 \pm 0$ and $2.33 \pm 0.33 \mathrm{~cm}$; width: $5.33 \pm 0.33$ and $1.33 \pm 0.33 \mathrm{~cm}$ respectively, Fig. $3 \mathrm{c}$ ).

For Penguin 4, a positive influence of the enrichment on the left foot lesion was found after the $7^{\text {th }}$ week of enrichment. In this animal, no lesion could be noted on the right feet (Fig.3d).

Penguin 5 showed contradictory results. While in the left foot a moderate improvement could be observed in width one week after enrichment (week 2), and in length in the last week of observation (week $12^{\text {th }}$ ); in the right foot, an increase in both width and length could be observed on the $6^{\text {th }}$ week after the beginning of enrichment (Fig. 3e).

\section{DISCUSSION}

In this study we tried to show that environmental conditions intended to meet the behavioral needs of Magellanic penguins are essential to maintain the quality of life of these animals in captivity. A retrospective study of Muller et al. (2000) showed that captive hawks needed to exercise through flying training to reduce morbidity caused by bumblefoot, because these birds kept in captivity usually had some abrasive contact on their feet, which is a predisposing factor to bumblefoot development. Young (2003), showed that, in species such as penguins, the probability of the development of this disease can be reduced by lessen the pressure on the feet with the use of pebbles as substrates. According to Erlacher- Reid et al. (2011), smooth flat substrates, such as concrete and increased weight are likely to increase pressure on the bony prominences and heels where lesions are usually located.

The stimulation of their permanence in the water by their interaction with enrichment items showed to be effective in reducing bumblefoot lesions (4 in 5 penguins) throughout the 12 weeks of observations, showing to have a direct relation between the increase of time spent in the water and the decrease of lesions. One animal (Penguin 5 ), which did not show any interest in interacting with the aquatic environmental enrichment, staying almost all of the time on the dry area, showed an increase of the lesions.

Despite receiving clinical treatment since the appearance of the lesions, this showed to be palliative, only controlling the worsening of lesions but not healing them completely. Improvement was only observed after the introduction of environmental enrichment items and the increase of time the animals spend in the water.

Once the animals are in constant contact with abrasive surfaces and with the clinical process installed, an efficient way to eliminate this problem is to stimulate the time spent in the water, since in the wild these animals spend most of their time foraging for food in the ocean (Stoskopf \& Stoskopf 1986, Williams 1995, Reidarson et al. 1999). The increase in the use of the aquatic environment, either by offering food in water (Reidarson et al. 1999), by stimulation of swimming (Wallace \& Walsh 2005) or by the introduction of aquatic enrichment items is also a way to prevent bumblefoot.

It is known that the number of animals in this study is very small, a fact that precluded the use of a control group, but we believe that our findings provide information that may assist in the management of penguins in captivity.

\section{CONCLUSION}

With these results we can suggest that an aquatic environmental enrichment may have improved the time these penguins spent in the water, favoring the reduction of the bumblefoot lesions. We suggest that environmental enrichment can be a great tool in providing a better quality of life for captive penguins as well as in helping to prevent and heal bumblefoot lesions.

\section{REFERENCES}

Bloomsmith M.A., Brent L.Y. \& Schapiro S.J. 1991. Guidelines for developing and managing an environment enrichment program for nonhuman primates. Lab. Anim. Sci. 41:372-376.

Boere V. 2001. Behavior and environmental enrichment, p.263-268. In: Fowler M.E. (Ed.), Biology, Medicine, and Surgery of South American Wild Animals. Iowa State University Press, Ames.

Cooper J.E. 1978. Veterinary Aspects of Captive Birds of Prey. Standfast Press, England.

Degernes L.A. 1994. Trauma Medicine, p.425-427. In: Ritchie B.W., Harrison G.J. \& Harrison L.R. (Eds), Avian Medicine: principles and application Wingers Publishing, Florida.

Erlacher-Reid C., Dunn J.L., Camp T., Macha L., Mazzaro L. \& Tuttle A.D. 2011. Evaluation of potential variables contributing to the development and duration of plantar lesions in a population of aquarium-maintained African penguins (Spheniscus demersus). Zoo Biology 30:1-5.

Harcourt-Brown N. 2000. Bumblefoot, p.126-131. In: Samour J. (Ed.), Avian Medicine. Mosby-Harcourt, London.

Maple T.L. \& Perkins L.A. 1996. Enclosure furnishings and structural environmental enrichment, p.212-222. In: Kleiman D.G., Allen M.E., Thompson K.V. \& Lumpkin S. (Eds), Wild Mammals in Captivity: principles and techniques Chicago University Press, Chicago.

Muller M.G., Wernery U. \& Kosters J. 2000. Bumblefoot and lack of exercise among wild and captive-bred falcons tested in the United Arab Emirates. Avian Dis. 44:676-680.

Oaks J.L. 1993. Immune and inflammatory responses in falcon staphylococcal pododermatitis, p.72-87. In: Redig P.T., Cooper J.E., Remple J.D. \& Hunter D.B. (Eds), Raptor Biomedicine Chiron Publications, Keighley, W. Yorkshire.

Redig P.T. 1993. Bumblefoot treatment in raptors, p.181-188. In: Fowler M.E. (Ed.), Zoo and Wild Animal Medicine. $3^{\text {rd }}$ ed. W.B. Saunders, Philadelphia.

Reidarson T.H., McBain J. \& Burch L. 1999. A novel approach to the treatment of bumblefoot in penguins. J. Avian Med. Surg. 13:124-127.

Reisfeld L., Barbirato M., Dutra C., Ippolito L., Cardoso R., Nichi M., Sgai M.G.F.G. \& Pizzutto C.S. 2010. Reducing bumblefoot lesions in a group of captive magellanic penguins (Spheniscus magellanicus) employing environmental enrichment. Proc. International Association of Aquatic Animal Medicine, p.126-127. (Abstract)

Remple J.D. \& Al-Ashbal A.A. 1993. Raptor bumblefoot: another look at histopathology and pathogenesis, p.92-98. In: Redig P.T., Cooper J.E., Remple J.D. \& Hunter D.B. (Eds), Raptor Biomedicine. University of Minnesota Press, Minneapolis.

Ruoppolo V., Adornes A.C., Nascimento A.C. \& Silva R.P. 2004. Reabilitação de pinguins afetados por petróleo. Clínica Vet. 51:72-83.

Shepherdson D.J. 1998. Tracing the path of environmental enrichment in zoos, p.1-12. In: Shepherdson D.J., Mellen J.D. \& Hutchins M. (Eds), Second Nature: environmental enrichment for captive animals. Smithsonian Institution Press, Washington, DC.

Stoskopf M.K. \& Stoskopf S.K. 1986. Aquatic birds, p.294-313. In: Fowler M.E. (Ed.), Zoo and Wild Animal Medicine. $2^{\text {nd }}$ ed. W.B. Saunders, Philadelphia.

Wallace R. \& Walsh M. 2005. Health, p. 86-104. In: Penguin Taxon Advisory Group (Eds), Penguin Husbandry Manual. $3^{\text {rd }}$ ed. American Zoo and Aquarium Association, Silver Spring, Maryland.

William T.D. 1995. The Penguins. Oxford University Press, Oxford. Young R.J. 2003. Environmental Enrichment for Captive Animal. Blackwell Publishing, Oxford. 